\title{
Analysis of Medical and Non-Medical Solid Waste Management in The District Health Center at Alahan Panjang in 2019
}

\author{
Luthfil Hadi Anshari ${ }^{1}$, Aria Gusti ${ }^{1}$, Ogid Meisi Ludipa ${ }^{1}$ \\ \{luthfilhadianshari@yahoo.com ${ }^{1}$ \} \\ Faculty of Public Health, Andalas University, Padang, Indonesia ${ }^{1}$
}

\begin{abstract}
In the implementation, the health center produces medical and non-medical waste that can disturb our health. If the waste is managed badly, it will impact on declining the health of the community and can cause health problems. Therefore, it is necessary to analyze problems related to medical and non-medical solid waste of health centers. This research was qualitative research. The informant of this research was selected using a purposive sampling technique consists of nine people who are competent in their skills. Depth interview was used to obtain the data, observations, and documentation guided by the decision of the minister of environment (KepmenLHK) No. 56/2015 and government regulations No. 81/2012 and analyzed by the descriptive narrative. The result of research refers to those input components related to human resources and facilities still insufficient in management. The sorting stage was still mixing medical and non-medical waste. No temporary trash bins available, and they transport manually. In the waste station, the waste was not processed immediately and ignore for several days. It indicates that medical and non-medical solid waste management at Alahan Panjang health center has not properly managed. The recommendations for Alahan Panjang health care are adding staff and facilities, and increase coordination, monitoring, and evaluation with relevant parties as though health centers, health offices, and environmental offices, and third- party.
\end{abstract}

Keywords: Medical and Non-Medical Waste, Health Care.

\section{Introduction}

Public Health Centers (Puskesmas) are health service organization units that aim as a center for developing health services. Puskesmas duties are to provide guidance, provide health services comprehensive and integrated with the people who live in a certain area. In carrying out their duties, the Community Health Center generates waste originating from medical or nonmedical services in the form of solid, liquid, and gas. Waste originating from health service facilities is estimated to be $75-90 \%$ of waste that does not contain risks such as domestic or household waste. The waste originates from administrative activities and daily installation, in addition to waste generated during the maintenance of the installation building. The remaining $10-25 \%$ is waste that is considered dangerous and can cause health impacts [1].

Based on the results of Pratiwi's research in 2016, there were $64.6 \%$ of health center that had carried out medical and non-medical waste sorting. However, only $26.8 \%$ of health centers have incinerator permits, while $73.2 \%$ do not have permits for these facilities, which shows that the management of solid medical waste is still poor. Alahan Panjang Health Center is located in 
Lembah Gumanti District. Alahan Panjang Health Center is an inpatient health center in Solok Regency. Alahan Panjang Health Center is one of the health centers with the highest amount of medical waste remittances. Based on data from the Solok District Health Office in 2018, the Alahan Panjang Health Center produced $105 \mathrm{~kg} / \mathrm{month}$ of solid medical waste. This amount is increased when compared to the amount of solid medical waste in 2017 of $52 \mathrm{~kg} /$ month [2].

This accumulation of waste causes a lot of waste and is dangerous because the waste undergoes a process of decomposition and decay. Then, the transportation of B3 waste is carried out every three days by PT Mufid Inti Global being transported to a third party, PT. Tenang Jaya Sejahtera, for processing waste once in six months. Alahan Panjang Health Center records the transportation of waste once a month. However, in 2019, the Solok District Health Office decided to collaborate with a third party beforehand. It was replaced with PT Berkah Rezeki Ikhlas as a carrier and medical waste manager due to delays in transportation from third parties.

Based on the annual report of the Alahan Panjang Health Center, the disposal of waste in the trash only reached $2.07 \%$ so that in the Puskesmas, there was still a pile of waste. The composition of medical waste contain syringes, drugs, contraceptives, IV tubes, IV tubes, gauze, bottles. In addition to medical waste, Alahan Panjang Health Center also produces non-medical waste. This waste is paper waste from the office, organic waste, waste from visitors, and waste from crop residues. The waste did not get special treatment and manage along with other waste. The waste collected at the TPS Puskesmas then transported by a waste truck, which is then processed by the Solok City regional landfill in collaboration with the Department of Environment of the Solok Regency.

Based on the initial survey, Alahan Panjang has carried out sorting according to its type. However, problems are still found in the management of medical and non-medical waste. There are no proper facilities and infrastructure. Trash bins are not cover with colored plastic bags according to their type. In the five types of rubbish bins, they only use plastic, which is a residual waste. For medical waste, the trash can still not be seen using plastic bags, but the waste is put directly into the trash without using a plastic bag. The waste transportation carried out by cleaning services is only one person, and he works as a security guard as well. However, since May 2019, the cleaning service has stopped working. The waste is transported by the clinic with health center health workers every 2-3 days.

Based on these problems, the authors are interested in conducting research on the Analysis of Medical and Non-Medical Waste Management in Alahan Panjang Public Health Center, Solok Regency in 2019. To analyze how the management of Medical and non-medical solid waste starting from waste sources to final treatment, and how resources are available in the processing of medical and non-medical solid waste at Alahan Panjang Health Center, Solok Regency.

\section{Method}

This is qualitative research with a descriptive approach. This research will be carried out from January to June 2019 at Alahan Panjang Health Center, Solok Regency, in 2019. Informants of this study are nine people, namely the Head of Environmental Health and Sports Work Health Section of the Health Office of Solok Regency, Head of the Waste and Waste Section of B3 of the District Environmental Agency Solok, Head of Alahan Panjang Health Center, Head of Health Center Administration, sanitary staff, nurses, doctors, pharmacists, and laboratory personnel. 
This data collection technique is derived from primary data and secondary data. Primary data were collected from observations and interviews. Then, secondary data is obtained from documentation and study of literature. The data analysis technique uses descriptive narratives with three channels, namely data reduction, data presentation, and conclusion drawing. Then the credibility of the data uses three ways, namely triangulation, using reference material, and member checking [3][4].

The research variables in the input component consist of human resources, funds, infrastructure facilities, and policies. Variables in the process component consist of sorting, storage, transportation, and processing and the output component is the implementation of waste management in the Alahan Panjang Health Center

\section{Results and Discussion}

The result of the research indicates some major problems in waste management. There is no staff responsible for transporting medical. The facilities and infrastructures are not adequate, and no Standard Operational Procedure (SOP) for managing medical waste. During the sorting, medical wastes are collected along with the other waste. The waste transported using the ambulance to the waste station. Sometimes, it took several days before they processed.

\subsection{Human Resources}

Based on the results of in-depth interviews, the management of medical and non-medical waste is carried out by environmental health personnel. Environmental Health Workers at Alahan Panjang Health Center are graduates of Public Health (SKM). The number of environmental health workers is one person, so that staff will have difficulty in carrying out field and office tasks if carried out at the same time. While the number of cleaners is not available.

This is in line with Manila and Sarto (2017) research that the number of environmental health workers per health center in Bantul Regency is one person. However, the number of cleaners in the Puskesmas is one to three people [5].

\subsection{Funds}

Based on the results of in-depth interviews, document review, and field observations made regarding funds in the management of solid medical and non-medical waste in Alahan Panjang Health Center that the Health Center has budgeted the funds for waste management. The fund budget used to manage medical and non-medical waste. It is used only for transporting the waste to the waste station, and for purchasing some utilities. The funds for waste management come from JKN Puskesmas Alahan Panjang.

This is in line with research by Nazila, Purwanti, and Prihanta (2017), which states that the source of funds for medical waste management comes from JKN or BOP. The budget is used for destruction / final disposal, plastic procurement, etc. [6].

\subsection{Facilities and Infrastructure}


Based on the results of in-depth interviews, document review, and field observations, Alahan Health Center has no adequate facilities and infrastructures. They have no transportation kit, such as trolleys, carts, and others. So, they transport the waste by hand.

This is in line with Yulianti's (2017) study that no equipment can be used for transporting medical and non-medical waste to temporary storage warehouses. In transportation, the staff removes the waste by hand since no transport kit available [7].

\subsection{Policy}

Based on the results of in-depth interviews, document reviews, and field observations, the health center already has an SOP for the storage and disposal of hazardous waste. The SOP has been socialized but not official.

Alahan Panjang Health Center has SOP regarding waste management, which is about processing hazardous waste as a guideline for storage and disposal, and non-medical waste SOP does not yet exist. However, the SOP is still in the stage of improvement. It has not used yet for the waste management process. Since the health center has not accreditated yet, so the SOP is under revision.

This is in line with research by Nazila, Purwanti, Prihanta (2017), which shows that the application of SOP has been carried out in all health center. However, for health centers that have not been accredited, the SOP is still under revision and needs approval from the head of the health center. The health centers have approved health center $\mathrm{E}$ and health center $\mathrm{F}$ in Malang that has been SOP accredited. Both SOP for accredited and not accredited is quite similar, only the SOP templates are different [6].

\subsection{Sorting}

Based on the results of the study, Alahan Panjang Health Center has separate waste bins for medical and non-medical waste. However, there is still a mixture of medical and nonmedical waste. It is because the label on the trash can fades, or there is not even a label in the trash can.

The placement of trash bins has been done evenly, but not all available bins have labels, so there is still mixing of medical and non-medical waste in one place. This is similar to the research of Rahno, Roebijoso, and Leksono (2015), which explains that there is no labeling on garbage bins so there is still mixing of medical and non-medical waste. This is not in accordance with PermenLHK No. 56 of 2015, which separates B3 waste based on the type, group, and/or characteristics of the waste [8][9].

\subsection{Storage}

Storage of waste carried out by environmental health personnel. Waste is collected daily from each trash can put in a sack and then stored in a warehouse. Trash is stored for one month. Trash that is often piled up in warehouses can become a vector of disease habitat so that it can transmit disease. In storage, the process carried out for medical waste is the same. However, the difference is storage. Since the permanent trash bins available, temporary non-medical wastes are stored together with the other waste. Meanwhile, medical waste storage has a building that is locked but not permanent.

This is in line with research by Nazila, Pratiwi, Pratinha (2017), which explains that the TPS of solid medical waste is closed (has a building) and is locked so that only officers can enter. The Meis waste storage building is made with a waterproof floor, is not corrugated, and has good walls and ventilation, is protected from rainwater entry, and is made without ceilings [6]. 


\subsection{Transportation}

From the research results, the Alahan Panjang Health Center does not have a special container. Transportation only uses sacks so that waste is easily scattered. When transporting the waste, you should use separate carts between medical and non-medical waste so that there are no difficulties in managing them. Sometimes there is still mixing of medical and nonmedical waste, making it vulnerable to disease transmission.

This is similar to the research of Khumaidi, Subagiyo, and Widiyanto (2016) that the transportation process is carried out by cleaning staff every afternoon. Transportation is done manually because there is no trolley for transporting medical waste from each room. According to PermenLHK No.56 of 2015, transportation of B3 waste must use a conveyance that has obtained a permit for transportation activities so that transportation is not in accordance with the provisions [10].

\subsection{Processing}

Officers who are responsible for processing waste are environmental health workers. The Health Center works together with third parties to do the processing. Processing is carried out by burning using incinerators for medical waste and sanitary landfills for non-medical waste.

The obstacle experienced by the parties in processing medical waste is the delay in transportation caused by the location of transportation and processing far away. Transportation from the health center to third parties is carried out once a month. The health center delivers to third parties with a predetermined schedule.

The same thing was explained in the study of Nazila, Pratiwi, and Prihanta (2017) that the obstacle experienced by the health center was PT.PRIA's delay in picking up solid medical waste in the health center. PT. Men usually take solid medical waste at each health center within 2-4 months. Medical waste that is stored for too long can cause an increased risk of bacterial and viral contamination. However, according to PermenLHK number 56 of 2015, it is explained that $\mathrm{B} 3$ waste is stored for a maximum of 90 days [6][9].

\section{Conclusion}

The management of medical and non-medical waste at the Alahan Panjang Health Center is not optimal and is not in accordance with the provisions. This is caused by the lack of human resources and facilities and infrastructure so that the process of sorting, storing, transporting, and processing is not going well. It is expected that the Alahan Panjang Health Center should add staff and facilities, improve the quality of work of health workers that produce waste, and improve coordination, monitoring, and evaluation with related parties such as health centers, health services, environmental services, and third parties.

\section{Suggestions}

1. To increase the number of environmental health workers and to increase cleaning personnel.

2. Carry out transportation facilities and special vehicles for medical and non-medical waste. 
3. Improving the quality (expertise) of environmental health workers by increasing education or holding training from the health department and then puskesmas conducting training on waste management to health workers who produce waste.

4. Labeling medical and non-medical waste containers, and renew labels that have faded.

5. Providing different colored bags for garbage bags, for example red for medical waste and black for non-medical waste.

6. Arrange properly medical waste and non-medical waste that will be transported so it is not scattered and dangerous.

7. Making non-medical waste TPS so as not to hitch a ride on the Alahan Panjang Market TPS and creating a permanent medical waste storage warehouse.

8. Making special lines for transporting medical and non-medical waste.

9. Reducing and managing simple non-medical waste such as waste banks, composting, and recycling the waste.

10. There needs to be increased coordination, monitoring, and evaluation between related parties such as the health department, the environmental service, puskesmas, cleaning staff, and third parties so that the management of medical and non-medical waste is more organized and better.

Acknowledgments: This study is part of the OML thesis, thank you to the Dean of the Faculty of Public Health, Andalas University, the supervisor lecturer for his guidance, to all lecturers and academic staff of the Faculty of Public Health, Andalas University, Alahan Panjang Health Center, Solok Regency who participated in helping this research.

\section{References}

[1] Wowor H, Liando DM, Rares J. Pelayanan Kesehatan di Pusat Kesehatan Masyarakat (Puskesmas) Amurang Timur Kabupaten Minahasa Selatan. Ilmu Sosial \& Pengelolaan Sumber Daya Pembangunan. 2016;3(XX):103-22.

[2] Pratiwi AS, Moesriati A. Inventarisasi Limbah Cair dan Padat Puskesmas di Surabaya Selatan sebagai Upaya Pengelolaan Lingkungan. Jurnal Teknik ITS. 2016;5(2):182-7.

[3] Suwendra IW. Metode Penelitian Kualitatif dalam Ilmu Sosial, Pendidikan, Kebudayaan, dan Keagamaan. Badung: Nilacakra; 2018.

[4] Satori Da, Komariah A. Metodologi Penelitian Kualitatif. Bandung: Alfabeta; 2010.

[5] Manila RL, Sarto. Evaluasi Sistem Pengelolaan Limbah Medis Puskesmas di Wilayah Kabupaten Bantul. BKM Journal of Community Medicine and Public Health. 2017;33(12):587-94.

[6] Azila NEN, Purwanti E, Prihatna W. Analisis Pengelolaan Sampah Medis Padat Puskesmas di Kota Malang sebagai Sumber Belajar Biologi. Prosiding Seminar Nasional III Tahun 2017 "Biologi, Pembelajaran, dan Lingkungan Hidup Perspektif Interdisipliner"; Malang: Universitas Muhammadiyah Malang; 2017. p. 317-23.

[7] Yulianti S. Analisis Sistem Pengelolaan Sampah Medis di Puskesmas Kota Sungai Penuh Tahun 2017 [SKRIPSI]. Padang: Universitas Andalas; 2017. 
[8] Rahno D, Roebijoso J, Leksono AS. Pengelolaan Limbah Medis Padat di Puskesmas Borong Kabupaten Manggarai Timur Provinsi Nusa Tenggara Timur. J-PAL. 2015;6(1):22-32.

[9] Tata Cara dan Persyaratan Teknis Pengelolaan Limbah Bahan Berbahaya dan Beracun dari Fasilitas Pelayanan Kesehatan, PermenKLH Nomor 56 tahun 2015 (2015).

[10] Khumaidi I, Subagiyo A, Widiyanto T. Analisis Pengolahan Limbah Medis Padat pada Dua Puskesmas Rawat Inap dan Dua Puskesmas Non Rawat Inap di Kabupaten Banyumas. Keslingmas. 2016;35:278-396. 